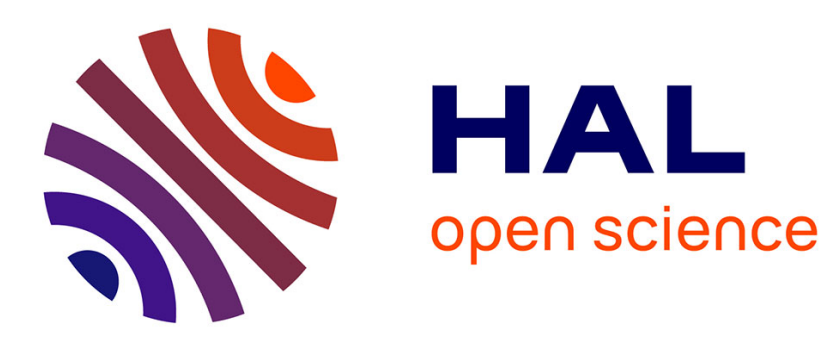

\title{
Enzymatic synthesis of alkyl beta-D-xylosides and oligoxylosides from xylans and from hydrothermally pretreated wheat bran
}

Marjorie Ochs, Murielle Muzard, Richard Plantier-Royon, Boris Estrine, Caroline Rémond

\section{To cite this version:}

Marjorie Ochs, Murielle Muzard, Richard Plantier-Royon, Boris Estrine, Caroline Rémond. Enzymatic synthesis of alkyl beta-D-xylosides and oligoxylosides from xylans and from hydrothermally pretreated wheat bran. Green Chemistry, 2011, 13 (9), pp.2380-2388. 10.1039/c1gc15719a . hal-02644956

\section{HAL Id: hal-02644956 \\ https://hal.inrae.fr/hal-02644956}

Submitted on 28 May 2020

HAL is a multi-disciplinary open access archive for the deposit and dissemination of scientific research documents, whether they are published or not. The documents may come from teaching and research institutions in France or abroad, or from public or private research centers.
L'archive ouverte pluridisciplinaire HAL, est destinée au dépôt et à la diffusion de documents scientifiques de niveau recherche, publiés ou non, émanant des établissements d'enseignement et de recherche français ou étrangers, des laboratoires publics ou privés. 
Green Chemistry

Cutting-edge research for a greener sustainable future
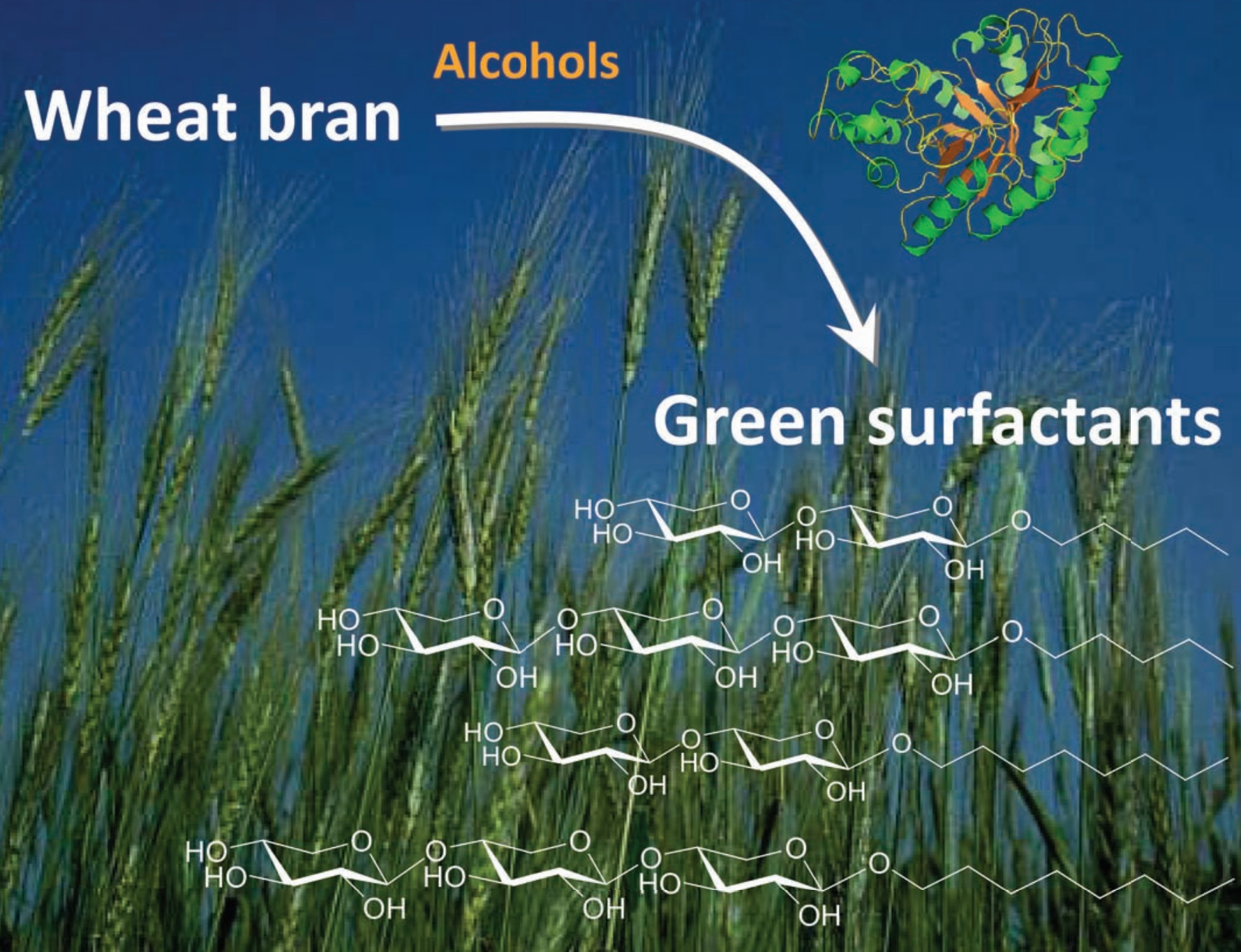


\title{
Green Chemistry
}

\section{Enzymatic synthesis of alkyl $\beta$-D-xylosides and oligoxylosides from xylans and from hydrothermally pretreated wheat bran}

\author{
Received 18th June 2011, Accepted 12th July 2011 \\ DOI: 10.1039/c1gc15719a

\begin{abstract}
Direct and efficient preparation of pentyl and octyl $\beta$-D-xylosides and oligoxylosides has been achieved from xylans and $n$-pentanol or $n$-octanol in aqueous medium with xylanases. The method has been successfully applied with xylooligosaccharides produced from hydrothermally pretreated wheat bran to produce octyl oligoxylosides. The pentose-based surfactants thus obtained exhibit good surface properties compared to other alkyl glycosides. These molecules represent interesting candidates for the production of new green surfactants.
\end{abstract}

Marjorie Ochs, ${ }^{a, b, c}$ Murielle Muzard, ${ }^{c}$ Richard Plantier-Royon, ${ }^{c}$ Boris Estrine ${ }^{d}$ and Caroline Rémond ${ }^{* a, b}$

\section{Introduction}

Lignocellulosic biomass is an abundant, renewable and lowcost energy source. The development of sustainable biorefineries from lignocelluloses requires to be based on multi-products concept aiming at producing bio-based molecules, biomaterials and bioethanol. ${ }^{1}$ Wheat which represents an important agricultural cereal in Europe generates large amounts of straw and bran during harvesting and milling processes. About 20000 billion tons of wheat grain and wheat straw which could produce 115 billion liters of bioethanol are lost as waste annually in Europe. ${ }^{2}$

Among the multi-steps envisaged in the conversion of lignocelluloses, notably the production of bioethanol, the first step is referred to as physical and/or chemical pretreatment. ${ }^{3-4}$ The subsequent steps concern the enzymatic hydrolysis of cellulose and the fermentation of the thus obtained glucose into ethanol. In this case, opportunities to improve the biorefinery concept could be related to hemicelluloses conversion and valorization. Indeed, when lignocellulosic ethanol is considered, hemicelluloses are potentially a bottleneck as the industrial fermentation of pentoses has not yet been achieved in a costefficient way. As example, the ethanol extraction-precipitation of arabinoxylans (AX) from bran has been proven and AX seems promising as a potential co-product for bioethanol production that would give process integration opportunities. ${ }^{5,6}$

INRA, UMR 614, Fractionnement des AgroRessources et Environnement, F-51686, Reims, France.

E-mail: caroline.remond@univ-reims.fr

${ }^{b}$ University of Reims Champagne Ardenne, UMR 614, Fractionnement des AgroRessources et Environnement, F-51686, Reims, France

'Université de Reims Champagne-Ardenne, Institut de Chimie

Moléculaire de Reims (ICMR), CNRS UMR 6229, UFR des Sciences

Exactes et Naturelles, Bâtiment 18 Europol'Agro, BP 1039, F-51687,

Reims, Cedex 2, France

${ }^{d} A-R-D$, Agro-Industrie Recherches et Développement "Green Chemistry

Department", F-51110, Pomacle, France
In this context, real economic and socio-technical possibilities exist for the development of bio-based value-added molecules and chemicals through lignocellulose biorefinery as an alternative for the petrochemical route. ${ }^{7-9}$ Alkyl glycosides are sugarbased nonionic surfactants currently used in liquid and powder detergents and in personal care products. ${ }^{10}$ Alkyl glycosides are mainly synthesized by a chemical route, performed by Fischer glycosidation or by Kœnigs-Knorr reaction. These methods generally require harsh conditions, generate non-recyclable wastes and are not stereospecific. Currently, mainly hexosebased surfactants are produced and studied. ${ }^{10,11}$ Nevertheless, pentose-based surfactants, particularly alkyl xylosides exhibit interesting surfactant properties ${ }^{12,13}$ and could be prepared from lignocellulosic biomass. Recently, a process fitting with Green Chemistry guidelines was developed to convert directly $\mathrm{AX}^{14}$ or biomass containing AX and starch into alkyl pentosides and hexosides. ${ }^{15}$ However, mixtures of alkyl glycosides were obtained (alkyl xylosides and alkyl glucosides).

Glycoside hydrolases cleave glycosidic bonds by acid-base catalysis. Besides these enzymes can also catalyze the transglycosylation of glycosyl residues to alcohols, producing alkyl glycosides. ${ }^{16-20}$ Xylanases naturally convert xylans into oligoxylosides and xylose units whereas xylosidases hydrolyse oligoxylosides into xylose units. The transglycosylation reactions occur when another acceptor than water is present in the reaction media. In this case, xylosidases produce alkyl xylosides ${ }^{13,21-23}$ and xylanases produce alkyl oligoxylosides. ${ }^{24-28}$ Enzymatic synthesis occurs in mild conditions and does not generate non-recyclable waste, in opposition to the chemical route. In addition, enzymes are stereoselective and the alkyl oligoglycosides that they produce could present different physico-chemical properties such as solubility compared to those obtained by classical chemistry.

Our work deals with the evaluation of transglycosylating capacities of two xylanases for the production of alkyl oligoxylosides in the presence of different sources of xylans as commercial xylans but also xylooligosaccharides generated 
from hydrothermally pretreated wheat bran (Fig. 1). The study focuses on several parameters influencing the synthetic capacity of the enzymes. Furthermore, our study comprises an evaluation of the surface properties of the alkyl oligoxylosides produced.

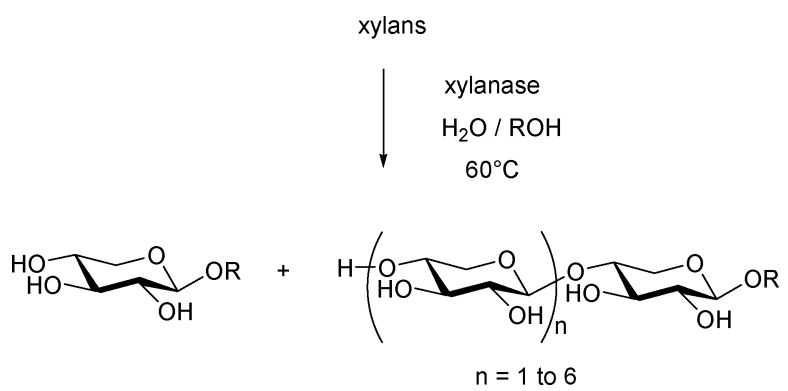

Fig. 1 General scheme of the transglycosylation reaction performed by a xylanase, where $\mathrm{R}$ is an alkyl group.

\section{Results and discussion}

\section{Enzymatic synthesis of alkyl $\beta$-D-oligoxylosides from xylans}

Transglycosylation reactions were performed with a xylanase from Thermobacillus xylanilyticus (Tx-xylanase) or a commercial xylanase (Novozymes NS-50030), using birchwood xylan and aliphatic alcohols with increasing chain length (from methanol to decanol). Both xylanases catalyse the synthesis of alkyl xylosides with better efficiency for short chain alcohols (chain length under 8 carbons) (data not shown). Experiments focused on the study of reaction parameters with the aim to induce the highest transglycosylation capacity of the Tx- xylanase and NS-50030 xylanase while using a partially water miscible alcohol (pentan-1-ol) and a non water-miscible alcohol (octan-1-ol).

To compare the transglycosylation efficiency of both enzymes, different reaction parameters such as xylan concentration, pentanol concentration, enzyme loading and duration of incubation were investigated on pentyl xylosides and oligoxylosides synthesis (Fig. 2). After preliminary experiments performed with 0.5 to $20 \%$ (w/v) xylan and 5 to $65 \%$ (v/v) pentanol, xylan and pentanol concentrations were respectively maintained at $2-5 \%$ and $5 \%$. These values represent the best compromise to insure the homogeneity of the reaction medium. First, the impact of the incubation duration was studied (Fig. 2a and 2b). The reaction catalyzed by $\mathrm{Tx}$-xylanase reached a maximum yield of $269.2 \mathrm{mg} \mathrm{g}^{-1}$ xylan for a $1 \mathrm{~h}$ incubation, then considerably decreased, probably due to secondary hydrolysis. Concerning the NS-50030 xylanase, a maximal yield of $465.3 \mathrm{mg} \mathrm{g}^{-1}$ of xylan was reached for a longer time of incubation $(3 \mathrm{~h})$. Nevertheless, the yield reached after $1 \mathrm{~h}$ incubation was $454.1 \mathrm{mg} \mathrm{g}^{-1}$ of xylan. Moreover, for incubation times longer than $3 \mathrm{~h}$ the total yields decreased, indicating a secondary hydrolysis of pentyl $\beta$ D-xylotrioside, resulting to an average degree of polymerization (DP) of 2.2 and 1.9 for a $1 \mathrm{~h}$ and $24 \mathrm{~h}$ incubation time respectively. This peculiarity was not observed for Tx-xylanase, as the average DP was 2.2 whatever the reaction time, indicating that the secondary hydrolysis occurred to a lesser extent. The effect of xylanase loading is presented in Fig. 2c and 2d. Increasing the enzyme concentration (from 1 to $40 \mathrm{IU} \mathrm{mL}^{-1}$ ) allowed to improve the yields of synthesis from 4.8 to $907.5 \mathrm{mg} \mathrm{g}^{-1}$ of xylan for Txxylanase and from 47.8 to $696.6 \mathrm{mg} \mathrm{g}^{-1}$ of xylan for the NS-50030 enzyme. The main difference between the reactions catalyzed by
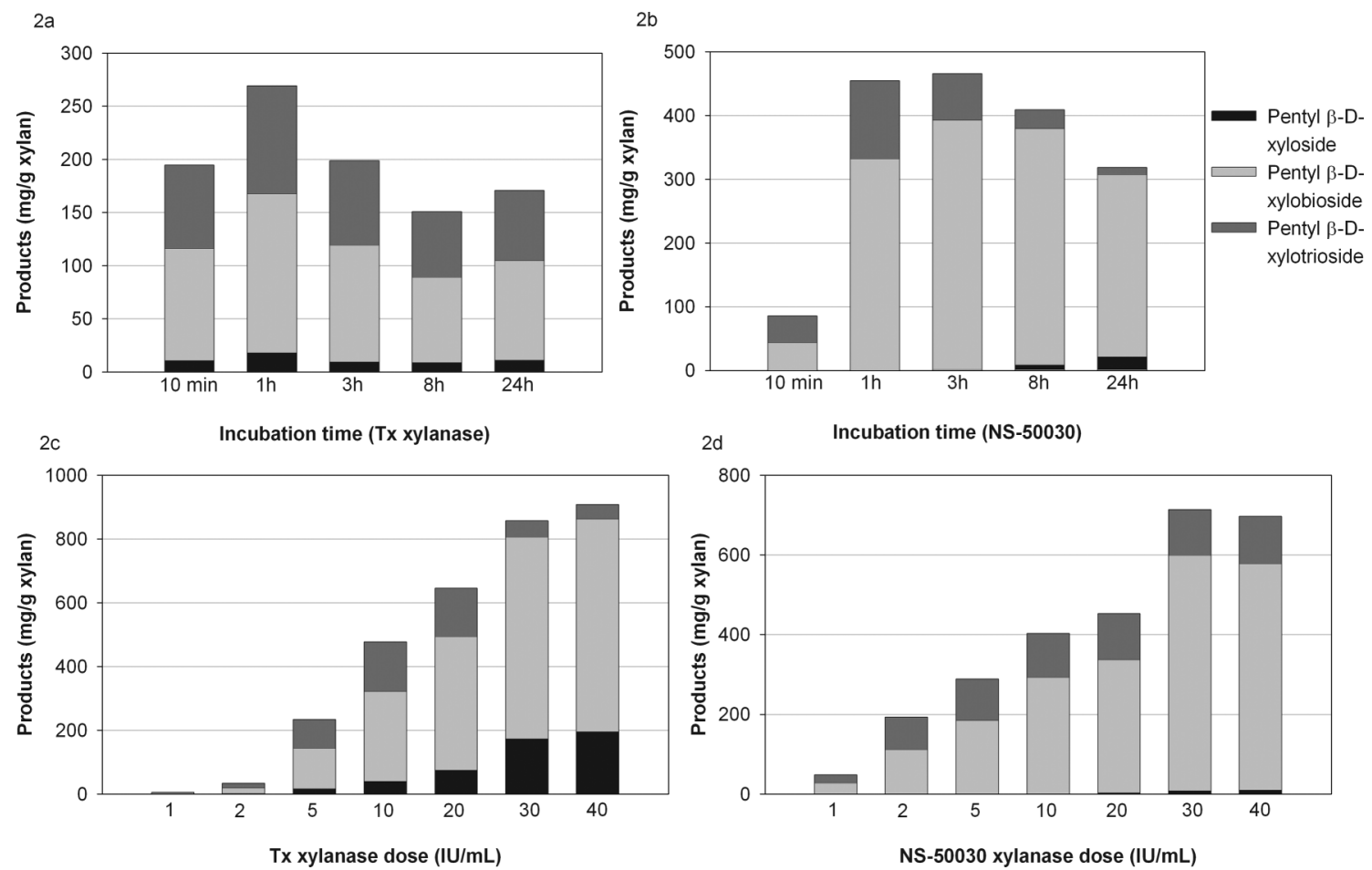

Fig. 2 Influence of reaction parameters on pentyl oligoxylosides synthesis. The reaction was performed at $60{ }^{\circ} \mathrm{C}(2 \mathrm{a}$ and $2 \mathrm{c})$ or at $50{ }^{\circ} \mathrm{C}(2 \mathrm{~b}$ and $2 \mathrm{~d})$ : $2 \%(\mathrm{w} / \mathrm{v})$ birchwood xylan, $5 \%(\mathrm{v} / \mathrm{v})$ pentanol, $2 \mathrm{IU} \mathrm{mL}^{-1}$ xylanase dose (2a and $\left.2 \mathrm{~b}\right) ; 5 \%(\mathrm{w} / \mathrm{v})$ birchwood xylan, $5 \%$ (v/v) pentanol, $1 \mathrm{~h}$ incubation time $(2 \mathrm{c}$ and $2 \mathrm{~d})$. 
the two xylanases concerns the DP of the products. Indeed, the commercial xylanase mainly synthesized pentyl $\beta$-D-xylobioside whereas pentyl $\beta$-D-xylotrioside was less abundant and pentyl $\beta$ D-xyloside was detected as traces only for high xylanase loading (up to $30 \mathrm{IU} \mathrm{mL} \mathrm{m}^{-1}$ ). In the case of Tx-xylanase, the major product was also pentyl $\beta$-D-xylobioside. Pentyl $\beta$-D-xylotrioside was synthesized but this product was less abundant when reactions were catalysed with a high loading of Tx-xylanase with a concomitant production of pentyl $\beta$-D-xyloside. These results indicate that secondary hydrolysis occurs with important enzymatic activity. Finally, the best conditions for $1 \mathrm{~mL}$ reaction were found with $5 \%(\mathrm{w} / \mathrm{v})$ xylan, $5 \%(\mathrm{v} / \mathrm{v})$ pentanol, $30 \mathrm{IU} \mathrm{mL} \mathrm{mL}^{-1}$ of xylanase for an incubation of $1 \mathrm{~h}$. In these conditions, the total yields were $857 \mathrm{mg} \mathrm{g}^{-1}$ xylan and the average DP was 1.8 with the Tx-xylanase. With the NS-50030 xylanase, the yield amounted $714 \mathrm{mg} \mathrm{g}^{-1}$ xylan and the average DP was 2.1 .

The effect of the xylan nature was also studied in order to evaluate whether L-arabinose moieties along the xylan main chains could impact the composition of alkyl xylosides. Transglycosylation reactions were tested with oat spelt xylan presenting high arabinose content $(\mathrm{L}-\mathrm{Ara} / \mathrm{D}-\mathrm{Xyl}=0.12)$ and compared to reactions conducted with birchwood xylan (LAra/D-Xyl $=0.003)$. In this case, reactions were catalysed by Tx-xylanase in the presence of pentan-1-ol. As observed by TLC analysis (Fig. 3), different products were obtained with oat spelt xylans compared to those obtained with birchwood xylan. The reaction carried out using birchwood xylan led to the detection of alkyl xylopyranosides 1, 2 and $\mathbf{4}$ for which NMR analysis indicated that they correspond respectively to pentyl$\beta$-D-xylopyranoside 1, pentyl- $\beta$-D-xylobioside 2 and pentyl- $\beta$-D-

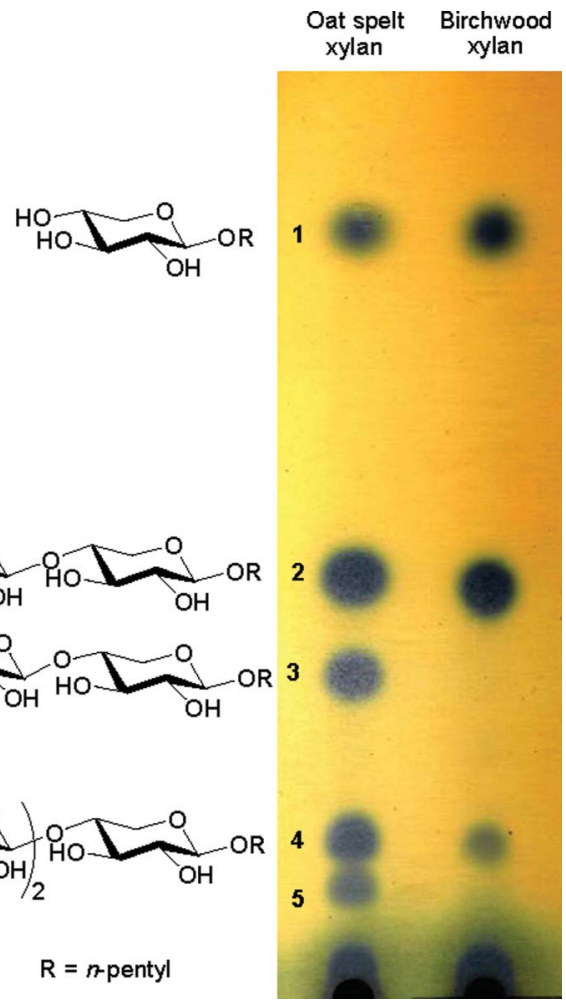

Fig. 3 Synthesis of pentyl oligoarabinoxylosides and pentyl oligoxylosides using different xylans. xylotrioside 4. Higher DP compounds (DP 4 to 7) were detected by mass spectrometry in the crude mixture after centrifugation but these products were not isolated. In the case of the reaction performed using oat spelt xylan, additional products $\mathbf{3}$ and 5 were detected. Structure of compound $\mathbf{3}$ was attributed to pentyl [ $3^{\prime}-O-\alpha$-L-arabinofuranosyl]- $\beta$-D-xylobioside. The determination of the structure of compound $\mathbf{5}$ was not established due to the small amount of purified product. We assume that this compound should be a L-arabinofuranosyl-substituted $n$ pentylxylotrioside.

These results show that various average DPs of alkyl oligoxylosides could be obtained by modifying some parameters such as the choice of the enzyme or the reaction time. This possibility could be of interest to generate surfactants with tailor made properties. Furthermore, the average DP obtained is higher than that obtained by chemical transglycosylation $(\mathrm{DP} \approx 1)$. Molecules with higher DP are known to present better water solubility due to their higher hydrophilic/lipophilic balance $(\mathrm{HLB})^{11}$ modifying the aggregation parameters of the alkyl oligoglycosides.

The synthesis of octyl xylosides and oligoxylosides was studied with Tx-xylanase, birchwood xylan and octan-1-ol. In the case of NS-50030, the transglycosylation yields were much lower (data not shown). In order to determine the optimal conditions for the production of octyl oligoxylosides, the effect of the Tx-xylanase dose and incubation time were studied. Increasing the xylanase dose from $2 \mathrm{IU} \mathrm{mL}^{-1}$ to $20 \mathrm{IU} \mathrm{mL}^{-1}$ led to an important shift of the yield of octyl xylosides produced, from $106 \mathrm{mg} \mathrm{g}^{-1}$ of xylan to $362 \mathrm{mg} \mathrm{g}^{-1}$ of xylan, respectively. When the xylanase dose was $30 \mathrm{IU} \mathrm{mL}^{-1}$, the total yield decreased to $315 \mathrm{mg} \mathrm{g}^{-1}$ of xylan and the average DP also decreased from 2.0 (with $2 \mathrm{IU} \mathrm{mL} \mathrm{m}^{-1}$ ) to 1.2. The results concerning the effect of the incubation time are presented in Fig. 4a. The total yield slightly increased from 362 to $390 \mathrm{mg} \mathrm{g}^{-1}$ xylan when the incubation time increased from $15 \mathrm{~min}$ to $30 \mathrm{~min}$. As observed for transglycosylation with pentan-1-ol, secondary hydrolysis appears for long incubation times, as the total yield decreased for incubations longer than $30 \mathrm{~min}$ and, as a consequence, the average DP decreased from 1.9 to 1.0 with increasing reaction times from $15 \mathrm{~min}$ to $3 \mathrm{~h}$.

An important limitation during the transglycosylation using long chain alcohols is the poor water solubility of the acceptor, which prevents it from an efficient contact with the enzyme and the donor. To minimize this physical effect, various parameters such as the stirring, the use of a co-solvent and the increase of the dose of octanol were studied. The effect of the stirring was observed by performing the transglycosylation without stirring or with a slow $(200 \mathrm{rpm})$ or a turbulent stirring $(1000 \mathrm{rpm})$. The corresponding results presented in Fig. $4 \mathrm{~b}$ demonstrate that a vigorous stirring is determinant, as the total yield shifted from $80 \mathrm{mg} \mathrm{g}^{-1}$ without stirring to $362 \mathrm{mg} \mathrm{g}^{-1}$ with a turbulent stirring. Secondly, the influence of the octanol dose was studied (Fig. 4c). Increasing the loading of the alcohol from 40 to $95 \%$ (v/v) during enzymatic synthesis of alkyl glycosides has already been studied ${ }^{28,29}$ and it seemed to increase yields. However, it has been recently reported that with $70 \%$ (v/v) octanol, and 5\% $(\mathrm{w} / \mathrm{v})$ xylan, the water phase was not important enough to allow a convenient mass transfer in the reaction media. ${ }^{29}$ Our study shows that octanol at $20 \%(\mathrm{v} / \mathrm{v})$ generates the higher yield of 


$$
4 a
$$
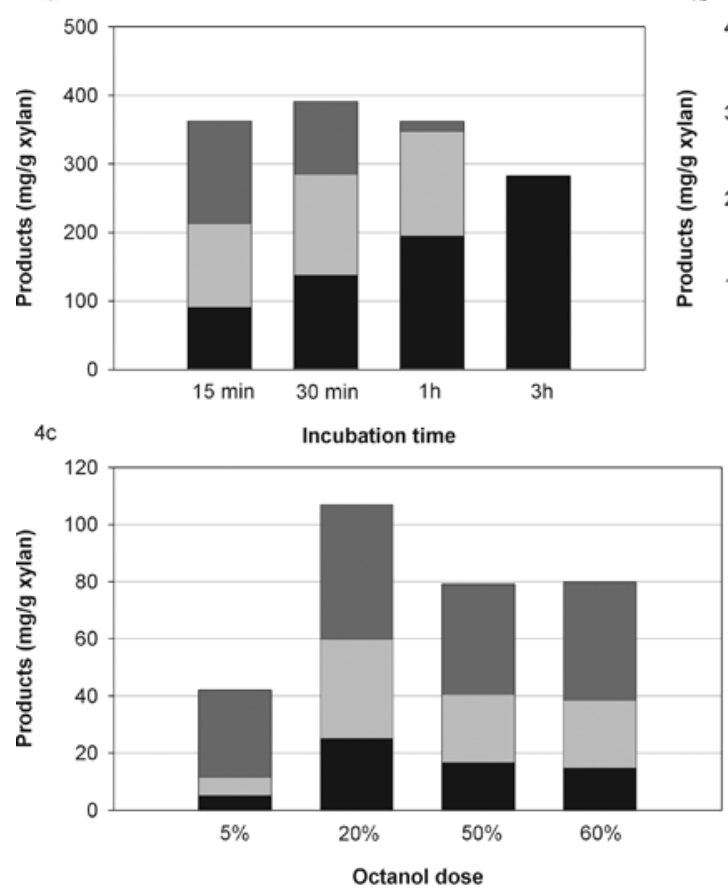

$4 \mathrm{~b}$

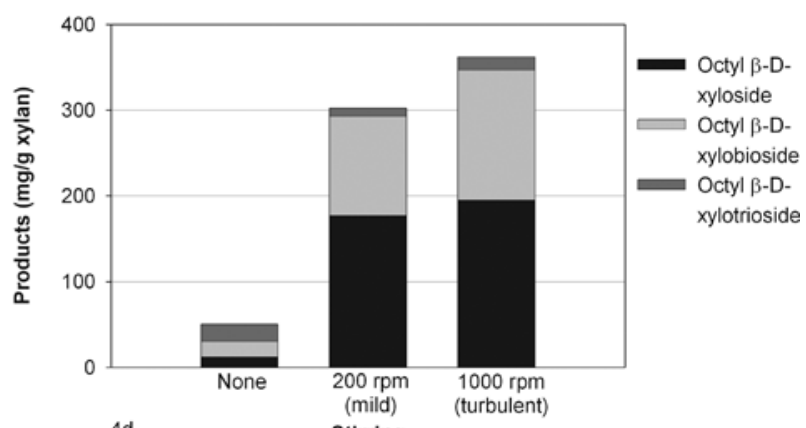

$4 d$

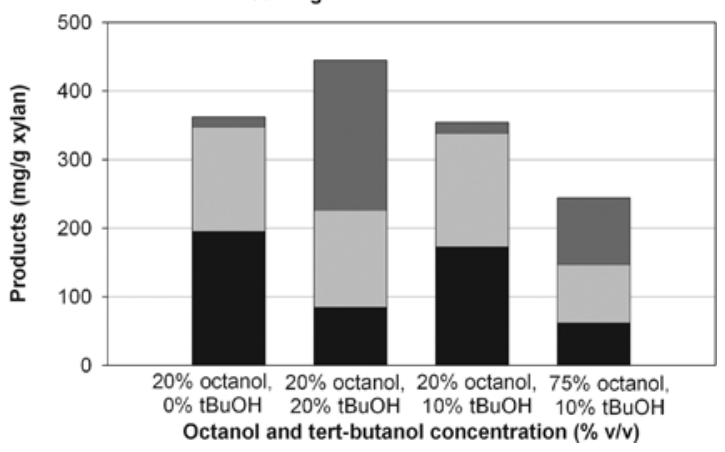

Fig. 4 Influence of reaction parameters on octyl oligoxylosides synthesis. The reactions were performed by the Tx-xylanase at $60{ }^{\circ} \mathrm{C}$ with $20 \%(\mathrm{v} / \mathrm{v})$ octanol, $20 \mathrm{IU} \mathrm{mL} \mathrm{mL}^{-1}$ xylanase, 5\% (w/v) birchwood xylan under $1000 \mathrm{rpm}$ stirring (a); with $20 \mathrm{IU} \mathrm{mL}^{-1}$ xylanase, 5\% (w/v) birchwood xylan, 20\% (v/v) octanol, $1 \mathrm{~h}$ incubation time (b); with $2 \mathrm{IU} \mathrm{mL}^{-1}$ xylanase, $5 \%$ (w/v) birchwood xylan, $1 \mathrm{~h}$ incubation time under $1000 \mathrm{rpm}$ stirring (c) and with $20 \mathrm{IU} \mathrm{mL} \mathrm{m}^{-1}$ xylanase, $5 \%$ (w/v) birchwood xylan, $1 \mathrm{~h}$ incubation time under $1000 \mathrm{rpm}$ stirring (d).

synthesis under turbulent stirring. These results are in good accordance with previous works, ${ }^{27}$ as we observed that for high concentrations of octanol in the reaction media (50 and 60\% $\mathrm{v} / \mathrm{v}$ ) the products yields approached $80 \mathrm{mg} \mathrm{g}^{-1}$ xylan whereas the yield was better (107 $\mathrm{mg} \mathrm{g}^{-1}$ xylan) for a reaction mixture containing $20 \%$ (v/v) octanol.

The last parameter studied was the addition of tert-butanol as a co-solvent in the reaction medium. Different combinations of octanol and co-solvent were tested. Experiments conducted with tert-butanol instead of octanol in the reaction media confirmed that no transglycosylation occurred in this case (data not shown). The reaction performed without co-solvent gave a total yield of $362 \mathrm{mg} \mathrm{g}^{-1}$ xylan. The less efficient ratio was octanol: tert-butanol $(75 \%: 10 \%)$, as the total yield amounted to $244 \mathrm{mg} \mathrm{g}^{-1}$ xylan for a xylanase dose of $20 \mathrm{IU} \mathrm{mL}^{-1}$ whereas the yields increased to 444 and $354 \mathrm{mg} \mathrm{g}^{-1}$ xylan when octanol : tertbutanol $(20 \%: 20 \%)$ or when octanol: tert-butanol $(20 \%: 10 \%)$ were used, respectively (Fig. 4d). In addition, the average DP of products is modified by the medium composition. The lowest average DP (1.4) is found when no tert-butanol was added in the reaction medium as in the case of octanol:tert-butanol $(20 \%: 10 \%)$, an average DP of 1.9 was observed when the media is composed of octanol: tert-butanol $(75 \%: 10 \%)$, and the ratio of octanol:tert-butanol (20\%:20\%) gave the highest average DP (2.1). These results are consistent with a previous study ${ }^{24}$ demonstrating that the use of co-solvents for the synthesis of benzyl oligoxylosides catalyzed by a xylanase increases the production of benzyl xyloside in regard to benzyl xylobioside and xylotrioside. However, this same study showed that the use of hexane as a co-solvent decreases the synthesis of hexyl oligoxylosides. The nature of the co-solvent probably influences the alkyl glycoside enzymatic synthesis yields, as it has been pointed out that the use of water miscible solvents in the reaction media increases the alkyl glucosides synthesis by a $\beta$ glucosidase. ${ }^{30}$ To our knowledge, it is the first time that high yield enzymatic synthesis of alkyl glycosides using tert-butanol in the reaction media is described.

In case of octylxylosides synthesis, the reaction mixture at the end of incubation contains 3 phases; an organic-based top phase, an aqueous-based bottom phase and an interphasic emulsion which hinders a reliable quantification by HPLC. This interphase was removed by adding a half volume of tertbutanol at the end of the incubation. The partition of the octyl oligoxylosides in an octanol-buffer system depending on their DP was recently studied and compared with this tert-butanol extraction. ${ }^{27}$ The tert-butanol extraction method we used totally removes the emulsion, and consequently the recovery of the products is easier. Thus, the distribution of the products in the two phases depending on their DP was evaluated (Fig. 5). As octyl $\beta$-D-xyloside 6 (95\%), octyl $\beta$-D-xylobioside 7 (88\%) and octyl $\beta$-D-xylotrioside $8(62 \%)$ were mainly localized in the octanol phase, we only quantified this phase in this study.

Using this method, the best reaction yields for $1 \mathrm{~mL}$ reaction were obtained with $5 \%(\mathrm{w} / \mathrm{v})$ xylan, $20 \%(\mathrm{v} / \mathrm{v})$ octanol, $20 \%$ (v/v) tert-butanol, $20 \mathrm{IU} \mathrm{mL} \mathrm{m}^{-1}$ of Tx-xylanase for a $1 \mathrm{~h}$ incubation. In these conditions, the total yield in the organic phase was $444 \mathrm{mg} \mathrm{g}^{-1}$ xylan $\left(84,142\right.$ and $218 \mathrm{mg} \mathrm{g}^{-1}$ xylan of octyl $\beta$-D-xyloside 6 , octyl $\beta$-D-xylobioside 7 and octyl $\beta$-Dxylotrioside 8 , respectively). These results are higher than those reported by Mamo et al..$^{27}$ who quantified 44 and $14 \mathrm{mg} \mathrm{g}^{-1}$ xylan 


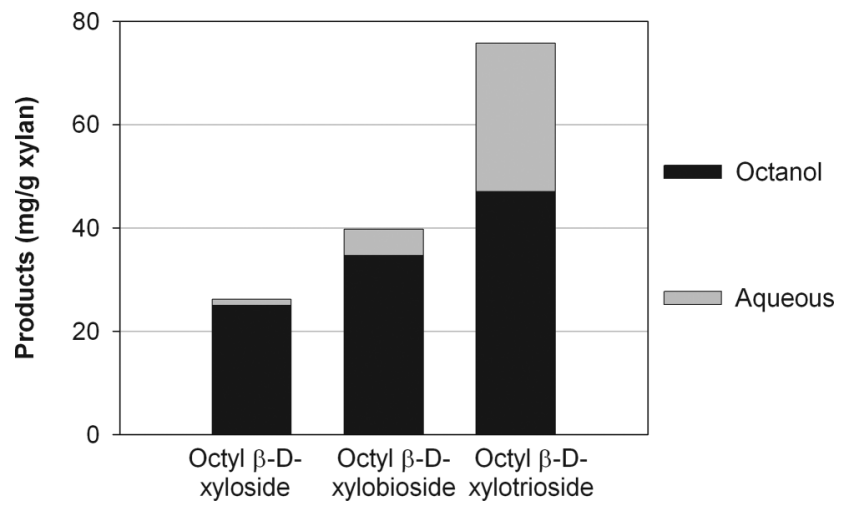

Fig. 5 Distribution of octyl oligoxylosides in aqueous and octanol phase, depending on their DP.

of $n$-octyl-xylobioside and xylotrioside, respectively, for a $2 \mathrm{~mL}$ reaction composed of $5 \%(\mathrm{w} / \mathrm{v})$ xylan, $1.4 \mathrm{~mL}$ octanol, $0.6 \mathrm{~mL}$ buffer and $0.1 \mathrm{U}$ xylanase, after an incubation of $9 \mathrm{~h}$.

\section{Scale-up of the enzymatic reactions}

According to the previous results, optimal conditions (birchwood and oat spelt xylans at 5\%(w/v), pentan-1-ol at 5\% (v/v) and NS-50030 xylanase (30 IU mL $\left.\mathrm{mL}^{-1}\right), 1 \mathrm{~h}$ incubation at $50{ }^{\circ} \mathrm{C}$ and a vigorous agitation) were used for the production of larger amounts of pentyl $\beta$-D-oligoxylosides required for the determination of their physico-chemical properties. As shown in Table 1, the yields of pentyl oligoxylosides $\left(449 \mathrm{mg} \mathrm{g}^{-1}\right.$ birchwood xylan) and pentyl arabinooligoxylosides $\left(313 \mathrm{mg} \mathrm{g}^{-1}\right.$ oat spelts xylan) produced by scaled-up reactions are lower than those found for a $1 \mathrm{~mL}$ reaction, whereas the average DP is relevant with the results obtained with the $1 \mathrm{~mL}$ reaction performed with the NS-50030 xylanase.

For octyl oligoxylosides synthesis birchwood xylans at 5\% (w/v), octan-1-ol at 20\% (v/v), tert-butanol at 20\% (v/v) and Tx-xylanase (20 IU mL $\mathrm{mL}^{-1}$ ), were incubated for $1 \mathrm{~h}$ duration at $60{ }^{\circ} \mathrm{C}$ using a vigorous agitation. Table 1 indicates that both the total yield of octyl oligoxylosides (132 $\left.\mathrm{mg} \mathrm{g}^{-1} \mathrm{xylan}\right)$ and the average DP (1.5 against 2.1$)$ were lower than the $1 \mathrm{~mL}$ reaction. In this case, these results could be attributed to the absence of tert-butanol addition to the remaining triphasic system obtained at the end of the enzymatic reaction.

\section{Direct enzymatic synthesis of octyl oligoxylosides from hydrothermally pretreated wheat bran}

Production of pentose-based surfactants could represent an interesting way to transform and valorize the pentose stream in a biorefinery concept. Among the pretreatments described for the biological production of second generation bioethanol, hydrothermal pretreatment which avoids the use of any chemical catalysts seems to be promising. ${ }^{3,31-32}$ In this context, a hydrothermal pretreatment of wheat bran was applied in order to recover the xylan from the bran cell walls into soluble xylooligosaccharides.

Destarched wheat bran ( $5 \mathrm{~g}$ containing $2 \mathrm{~g}$ of $\mathrm{AX}$ ) was suspended in a concentration of $10 \% \mathrm{w} / \mathrm{v}$ in water and autoclaved for $1 \mathrm{~h}$ at $135{ }^{\circ} \mathrm{C}$. In these unoptimized conditions, $16.1 \%$ (322 mg) of the arabinoxylans contained in the bran were solubilized. After filtration, the resulting solution was lyophilized and used as a substrate in a $2 \%(\mathrm{w} / \mathrm{v})$ arabinoxylan equivalent for a $1 \mathrm{~h}$ reaction in the presence of octan-1-ol $(20 \%$, $\mathrm{v} / \mathrm{v})$, tert-butanol $(20 \%, \mathrm{v} / \mathrm{v})$ and Tx-xylanase $\left(20 \mathrm{IU} \mathrm{mL}^{-1}\right)$. The total yield was higher ( $222.2 \mathrm{mg} \mathrm{g}^{-1}$ arabinoxylan equivalent) when using the supernatant obtained from pretreated wheat bran than when $2 \%(\mathrm{w} / \mathrm{v})$ birchwood xylan was used as substrate (146.6 $\mathrm{mg} \mathrm{g}^{-1}$ arabinoxylan equivalent) (Fig. 6). In addition, the average DP was higher (1.9) with the supernatant from hydrothermally pretreated wheat bran than with xylan (1.7). In these conditions, the yield of synthesis using destarched wheat bran as the substrate without pretreatement was very low $(3.5 \mathrm{mg}$ $\mathrm{g}^{-1}$ arabinoxylan equivalent).

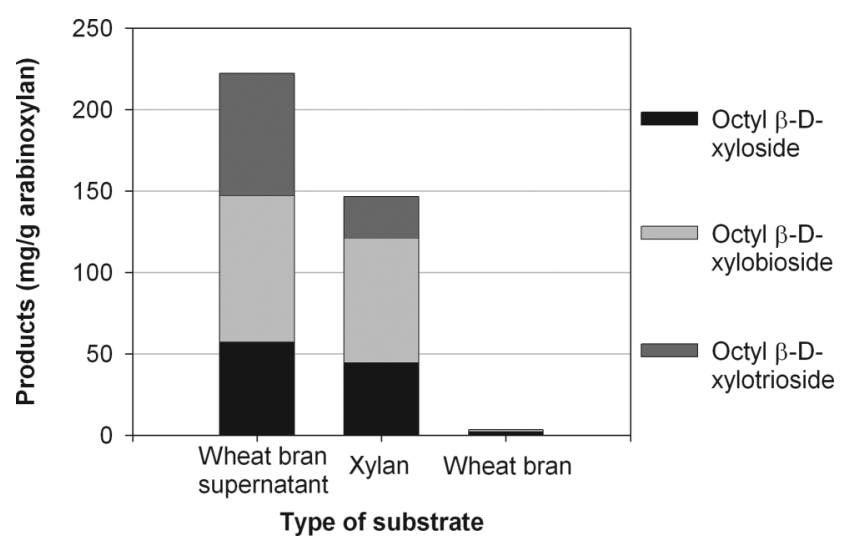

Fig. 6 Influence of substrate for octyloligoxylosides synthesis.

\section{Surface active properties of pentyl and octyl $\beta$-D-oligoxylosides}

The scaled-up reactions were used for surface active properties analysis. The surface tension of the supernatants solution obtained after transglycosylation using pentan-1-ol, the commercial xylanase and birchwood or oat spelt xylan, was investigated as a function of supernatants concentration and compared to

Table 1 Scale-up reaction yields and average DP

\begin{tabular}{|c|c|c|c|c|c|}
\hline \multirow[t]{3}{*}{ Origin of xylan } & \multirow[t]{2}{*}{ Reaction volume } & \multicolumn{3}{|c|}{ Products Yields ( $\mathrm{mg} \mathrm{g}^{-1}$ xylan) and DP } & \multirow[t]{2}{*}{ Average DP } \\
\hline & & Penty & noolig & & \\
\hline & & DP 1 & DP 2 & DP 3 & \\
\hline Birchwood & $500 \mathrm{~mL}$ & 22.0 & 331.6 & 95.0 & 2.1 \\
\hline \multirow[t]{2}{*}{ Oat spelts } & $700 \mathrm{~mL}$ & 11.9 & 245.8 & 55.6 & 2.1 \\
\hline & & $\begin{array}{l}\text { Octyl } \\
\text { DP } 1\end{array}$ & DP 2 & DP 3 & \\
\hline Birchwood & $1400 \mathrm{~mL}$ & 56.1 & 68.3 & 7.8 & 1.5 \\
\hline
\end{tabular}


$7 a$

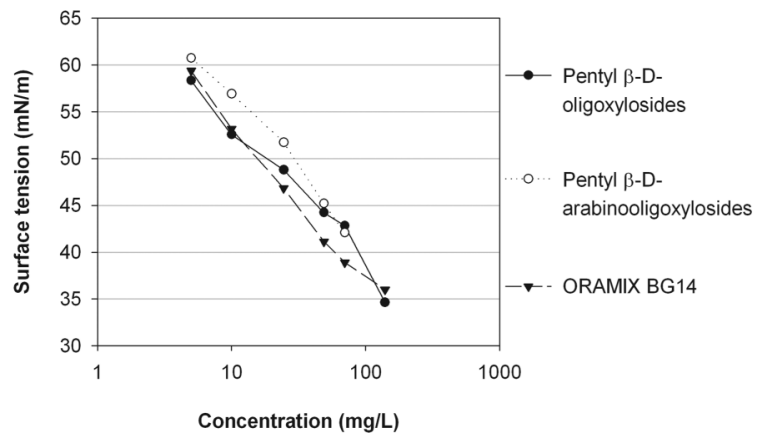

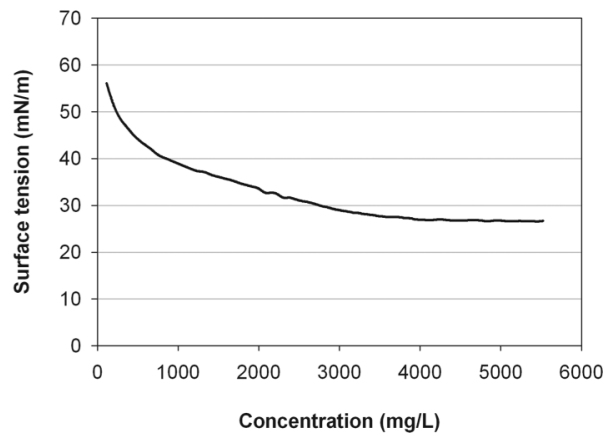

Fig. 7 Surface tension of pentyl oligoarabinoxylosides compared to industrial surfactants (a) and octyl oligoxylosides (b).

a commercial butyl glucosides (Oramix BG14®) (Fig. 7a). Hydrotrope behaviors were observed for butyl glucosides, pentyl $\beta$-D-oligoxylosides, and the pentyl $\beta$-D-arabinoxylooligosides, as no surface tension curve inflexion appeared along the concentration range studied. On the other hand, pentyl oligopentoside mixtures originating from the enzymatic process, in opposition to the commercial glucosides made from acid catalysed glycosylation, contain residual xylan due to hydrolysis side reaction. The presence of xylan impurities in the pentyl-pentosides does not induced lower hydrotrope properties as the surface tension curves were similar to butylglucosides. As soluble arabino-xylan does not possess any surface activity (data not shown), the surface tension modification observed can be attributed to the alkyl oligosides present in the bulk mixture. Obviously, their presence induces a sort of dilution of the surface activity and it would be possible to improve this by minimizing the hydrolysis of the AX during the enzymatic process. These results demonstrate the application potential of the pentyl oligoxylosides produced with our process as, for example, short tail glycosides with similar properties are efficient ingredients in the preparation of environmentally friendly wetting agents for the wood-based industry. ${ }^{33}$ Finally, concerning the pentyl oligoxylosides, it is important to point out the fact that no significant difference was observed between the products obtained from birchwood xylan and the products obtained from oat spelt xylan. These results indicate that the presence of arabinosyl moieties along the xylan polysaccharides chain does not impact the hydrotrope behaviour of the glycoside supernatants solutions.

The surface tension of octyl $\beta$-D-xylooligosides solution obtained from the tranglycosylation of octan-1-ol, birchwood xylan and the Tx-xylanase are shown in Fig. 7b. As it can be clearly observed by the inflexion point of the surface tension curve, the octyl $\beta$-D-xylooligosides display a CMC value of $4.23 \mathrm{~g} \mathrm{~L}^{-1}$ and a $\gamma_{\mathrm{CMC}}$ of $27.0 \mathrm{mN} \mathrm{m}^{-1}$. This behaviour clearly shows that we can envisage detergent applications for these compounds. Surfactants are most effective at or above their critical micelle concentration (CMC). In a detergent process, as the micelles solubilize the soil, the concentration of available micelles is reduced and the surfactant becomes less effective. Therefore, it is usual to develop a detergent where the surfactant solutions will be used in concentrations that are 2 to 10 times their CMC. This technique allows for some of the surfactant micelles to be used up during the washing process without reducing the cleaning efficiency. In this context, the selection of surfactants with the lowest CMC is obvious and noteworthy when economics are considered.

Table 2 presents the CMC, and $\gamma_{\mathrm{CMC}}$ data for other octylglycosides with structural similarities so as to evaluate the efficiency of the produced octyl $\beta$-D-xylooligosides.

First of all, it is important to point out that the effectiveness (displayed by surface tension at CMC, i.e. $\gamma_{\mathrm{CMC}}$ ) of all glycosides is similar whatever the nature of the polar head group (carbohydrate origin, and type of glycoside linkage). Concerning the CMC data, the oligoxylosides are less efficient in surface tension lowering compared to monoxylosides. This is obviously due to the differences between glycosidic bounds ( $\alpha$ and $\beta$ for the monoxylosides) as also displayed by the CMC values for $\alpha$ - and $\beta$-octyl-monoglucosides. Indeed, it is known that $\beta$ glycosides are more water soluble than their $\alpha$ anomers and that the solubility greatly influences the aggregation parameter. ${ }^{34}$ On the other hand, it is important to compare the CMC of oligoxylosides with the one of a structurally similar octyl $\beta$ $\mathrm{D}$-maltoside ( $\mathrm{DP}=2$ ). Here, the CMC difference is probably due to the nature of the constitutive carbohydrate unit of the polar head group as already observed for monoglucosides and monoglycosides. Finally, it is also important to refer to the CMC value of an industrially available oligoglucosides mixtures obtained from an acid catalysed process that yields $\alpha$ - and

Table 2 Critical micelle concentration $(\mathrm{CMC})$ and static surface tension $\left(\gamma_{\mathrm{CMC}}\right)$ of octyl glycosides with different glucose-based head groups

\begin{tabular}{lll}
\hline Surfactant & CMC $\left(\mathrm{mg} \mathrm{L}^{-1}\right)$ & $\gamma_{\mathrm{CMC}}\left(\mathrm{mN} \mathrm{m}^{-1}\right)$ \\
\hline Octyl $\alpha / \beta$-D-xylosides $(\mathrm{DP}=1)^{14}$ & 953 & 27 \\
Octyl $\beta$-D-oligoxylosides (enzymatic process; DP > 2) $^{34}$ Octyl $\alpha$-D-glucoside $^{34}$ & 4230 & 27 \\
Octyl $\alpha / \beta$-D-oligoglucoside $^{35}$ & 3500 & 26 \\
Octyl $\beta$-D-glucopyranoside $^{35}$ & 7632 & 26 \\
Octyl $\beta$-D-maltoside $^{34}$ & 10600 & 26 \\
\hline
\end{tabular}


$\beta$-glycosides. Due to the lower CMC of the oligoxylosides compared with this industrial product, it is also possible to envisage similar industrial uses confirming the interest of our new enzymatic process.

\section{Experimental section}

\section{Materials}

Pentan-1-ol and octan-1-ol were purchased from Sigma-Aldrich Corp. (St. Louis, USA). Destarched wheat bran was provided by ARD (Pomacle, France). Birchwood xylan and oat spelt xylans were obtained from Carl Roth (Karlsruhe, Germany) and TCI (Tokyo, Japan), respectively. A purified thermophilic endo-xylanase was purchased from Novozymes (NS-50030). A recombinant thermophilic family 10 endo-xylanase (Txxylanase) from Thermobacillus xylanilyticus was produced by E. coli BL21(DE3) using a previously established protocol. ${ }^{36}$ In this latter case, the cell pellet corresponding to $1.6 \mathrm{~L}$ of culture media was re-suspended with $35 \mathrm{~mL}$ of phosphate/ $\mathrm{NaCl}$ buffer (pH 7.4). Cells were broken by 2 passages in a French press apparatus at 16000 psi. The solution was then centrifugated for $20 \mathrm{~min}$ at $6000 \mathrm{~g}$ in order to eliminate the cellular fragments. The supernatant was heated at $60^{\circ} \mathrm{C}$ for $30 \mathrm{~min}$ in order to precipitate the protein from $E$. coli. It was then centrifugated for $20 \mathrm{~min}$ $(2000 \mathrm{~g})$. Finally, the supernatant obtained was filtrated on $0.2 \mu \mathrm{m}$ membrane. Activities of both xylanases were determined using the method of reducing sugars previously described. ${ }^{37}$

\section{Enzymatic synthesis of alkyl $\beta$-D-oligoxylosides}

Enzymatic reactions $(1 \mathrm{~mL})$ were carried out in closed glass vessels with a magnetic stirrer and were incubated in a thermostated oil bath for $1 \mathrm{~h}$ at $60{ }^{\circ} \mathrm{C}$ (Tx-xylanase) or $50{ }^{\circ} \mathrm{C}$ (NS-50030 commercial xylanase). The reactions were stopped by incubating the reaction mixtures for $10 \mathrm{~min}$ at $100{ }^{\circ} \mathrm{C}$ and centrifugating them for $10 \mathrm{~min}(2000 \mathrm{~g})$ in order to pellet the residual xylan.

\section{Purification, characterization and quantification of the transglycosylation products}

The qualitative analysis was performed by TLC, using Kieselgel $60 \mathrm{~F}_{254}$ aluminium-backed sheets (E. Merck) and EtOAc:HOAc: water $(7: 2: 2)$ as the mobile phase. Products were detected at $130{ }^{\circ} \mathrm{C}$ using $0.2 \%$ (v/v) orcinol in $\mathrm{H}_{2} \mathrm{SO}_{4}(20 \%$, $\mathrm{v} / \mathrm{v})$.

NMR spectra were recorded on a Bruker spectrometer (500 $\mathrm{MHz}$ for ${ }^{1} \mathrm{H}$ and $125 \mathrm{MHz}$ for ${ }^{13} \mathrm{C}$ ). Chemical shifts are expressed in parts per million (ppm) using TMS as an internal standard. Coupling constants are in hertz and pattern abbreviations are as follows: $\mathrm{s}$ singlet, $\mathrm{d}$ doublet, $\mathrm{t}$ triplet, $\mathrm{q}$ quartet, qu quintet, m multiplet. Mass spectra (MS) and high resolution mass spectra (HRMS) were performed on a Q-TOF Micro micromass positive ESI $(\mathrm{CV}=30 \mathrm{~V})$.

After centrifugation to eliminate the residual xylan, the crude reaction for pentyl $\beta$-D-oligoxylosides was filtered, lyophilized and the residue was extracted with EtOAc: $\mathrm{MeOH}(1: 1)$. The organic-based phase for octyl $\beta$-D-oligoxylosides was filtered and concentrated under reduced pressure. The purification of transglycosylation products with a DP up to 3 was achieved by using silica gel chromatography (9385 Merck Kieselgel 60, 230-400 mesh, 40-63 $\mu \mathrm{m}$ ) with a gradient EtOAc: $\mathrm{MeOH}$ (from $90: 10$ to $70: 30$ ) as the mobile phase. These compounds were identified by ${ }^{1} \mathrm{H}$ and ${ }^{13} \mathrm{C}-\mathrm{NMR}\left(\mathrm{D}_{2} \mathrm{O}, 500 \mathrm{MHz}\right.$ for ${ }^{1} \mathrm{H}$ and $125 \mathrm{MHz}$ for ${ }^{13} \mathrm{C}$ ), COSY, ${ }^{1} \mathrm{H}_{-}{ }^{13} \mathrm{C}$ correlation experiments and ESI-MS or ESI-HRMS

Pentyl-p-D-xylopyranoside 1. White solid, mp $72{ }^{\circ} \mathrm{C}$. $[\alpha]_{\mathrm{D}}^{20}$ -54.4 ( $c 0.32$ in $\mathrm{MeOH}) .{ }^{1} \mathrm{H}$ NMR $\left(\mathrm{D}_{2} \mathrm{O}, 500 \mathrm{MHz}\right): \delta 0.80(\mathrm{t}$, $J=7.5 \mathrm{~Hz}, 3 \mathrm{H}), 1.26,1.30$ and $1.50\left(\mathrm{~m}, 3 \times \mathrm{CH}_{2}\right), 3.16(\mathrm{dd}$, $J=7.9 \mathrm{~Hz}, J=9.3 \mathrm{~Hz}, \mathrm{H}-2), 3.23(\mathrm{t}, J=11.6 \mathrm{~Hz}, \mathrm{H}-5), 3.34(\mathrm{t}$, $J=9.2 \mathrm{~Hz}, \mathrm{H}-3), 3.50-3.56$ (m, H-4), 3.59 (dt, $J=6.8 \mathrm{~Hz}, J=$ $9.8 \mathrm{~Hz}, 1 \mathrm{H}), 3.78(\mathrm{dt}, J=6.8 \mathrm{~Hz}, J=9.8 \mathrm{~Hz}, 1 \mathrm{H}), 3.86(\mathrm{dd}, J=$ $5.6 \mathrm{~Hz}, J=11.4 \mathrm{~Hz}, \mathrm{H}-5), 4.32$ (d, $J=7.9 \mathrm{~Hz}, \mathrm{H}-1) ;{ }^{13} \mathrm{C} \mathrm{NMR}$ $\left(\mathrm{D}_{2} \mathrm{O}, 125 \mathrm{MHz}\right) \delta 13.2\left(\mathrm{CH}_{3}\right), 21.6,27.8$ and $28.4\left(3 \times \mathrm{CH}_{2}\right)$, 65.0 (C-5), 69.1 (C-4), $70.7\left(\mathrm{OCH}_{2}\right), 72.9$ (C-2), 75.7 (C-3), 102.8 (C-1); ESI-MS: $243.1(\mathrm{M}+\mathrm{Na})^{+}$.

Pentyl- $\beta$-D-xylobioside 2. White solid, mp $45^{\circ} \mathrm{C}$. $[\alpha]_{\mathrm{D}}^{20}-49.0$ (c 0.49 in $\mathrm{MeOH}) .{ }^{1} \mathrm{H} \mathrm{NMR}\left(\mathrm{D}_{2} \mathrm{O}, 500 \mathrm{MHz}\right): \delta 0.86(\mathrm{t}, J=$ $7.0 \mathrm{~Hz}, 3 \mathrm{H}), 1.30$ and $1.31\left(\mathrm{~m}, 2 \times \mathrm{CH}_{2}\right), 1.60(\mathrm{qu}, J=7.0 \mathrm{~Hz}$, $2 \mathrm{H}), 3.23\left(\mathrm{dd}, J=7.9 \mathrm{~Hz}, J=9.2 \mathrm{~Hz}, \mathrm{H}-2^{\prime}\right), 3.25(\mathrm{dd}, J=7.9 \mathrm{~Hz}$, $J=9.2 \mathrm{~Hz}, \mathrm{H}-2), 3.28$ (dd, $\left.J=10.4 \mathrm{~Hz}, J=11.5 \mathrm{~Hz}, \mathrm{H}-5^{\prime}\right), 3.36$ (dd, $J=10.2 \mathrm{~Hz}, J=11.8 \mathrm{~Hz}, \mathrm{H}-5), 3.41$ (t, $\left.J=9.3 \mathrm{~Hz}, \mathrm{H}-3^{\prime}\right)$, $3.53(\mathrm{t}, J=9.2 \mathrm{~Hz}, \mathrm{H}-3), 3.60(\mathrm{ddd}, J=5.4 \mathrm{~Hz}, J=9.3 \mathrm{~Hz}$, $\left.J=10.4 \mathrm{~Hz}, \mathrm{H}-4^{\prime}\right), 3.65(\mathrm{dt}, J=6.8 \mathrm{~Hz}, J=9.8 \mathrm{~Hz}, 1 \mathrm{H}), 3.84$ $(\mathrm{dt}, J=6.8 \mathrm{~Hz}, J=9.8 \mathrm{~Hz}, 1 \mathrm{H}), 3.75(\mathrm{ddd}, J=5.3 \mathrm{~Hz}, J=$ $9.2 \mathrm{~Hz}, J=10.2 \mathrm{~Hz}, \mathrm{H}-4), 4.39$ (d, $J=7.9 \mathrm{~Hz}, \mathrm{H}-1), 4.44$ (d, $\left.J=7.8 \mathrm{~Hz}, \mathrm{H}-1^{\prime}\right) ;{ }^{13} \mathrm{C} \mathrm{NMR}\left(\mathrm{D}_{2} \mathrm{O}, 125 \mathrm{MHz}\right) \delta 13.2\left(\mathrm{CH}_{3}\right)$, 21.6, 27.3 and $28.4\left(3 \times \mathrm{CH}_{2}\right), 62.8(\mathrm{C}-5), 65.1\left(\mathrm{C}-5^{\prime}\right), 69.1(\mathrm{C}-$ $\left.4^{\prime}\right), 70.8\left(\mathrm{OCH}_{2}\right), 72.7\left(\mathrm{C}-2^{\prime}\right), 72.9(\mathrm{C}-2), 73.8(\mathrm{C}-3), 75.5\left(\mathrm{C}-3^{\prime}\right)$, 76.3 (C-4), 101.8 (C-1'), 102.7 (C-1); ESI-HRMS: $m / z$ calcd for $\mathrm{C}_{15} \mathrm{H}_{28} \mathrm{O}_{9} \mathrm{Na}:[\mathrm{M}+\mathrm{Na}]^{+}:$375.1631, found: 375.1639 .

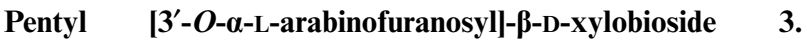
Amorphous solid. $[\alpha]_{\mathrm{D}}^{20}-72.7$ (c 0.15 in $\left.\mathrm{MeOH}\right) .{ }^{1} \mathrm{H}$ NMR $\left(\mathrm{D}_{2} \mathrm{O}, 600 \mathrm{MHz}\right): \delta 0.79(\mathrm{t}, J=7.0 \mathrm{~Hz}, 3 \mathrm{H}), 1.23-1.25(\mathrm{~m}, 2 \times$ $\mathrm{CH}_{2}$ ), 1.53 (qu, $\left.J=7.0 \mathrm{~Hz}, 2 \mathrm{H}\right), 3.18(\mathrm{dd}, J=9 \mathrm{~Hz}, J=8 \mathrm{~Hz}$, $\mathrm{H}-2), 3.25$ (t, $\left.J=11 \mathrm{~Hz}, \mathrm{H}-5^{\prime}\right), 3.27$ (t, $\left.J=11 \mathrm{~Hz}, \mathrm{H}-5\right), 3.32$ $\left(\mathrm{dd}, J=9 \mathrm{~Hz}, J=8 \mathrm{~Hz}, \mathrm{H}-2^{\prime}\right), 3.45-3.47$ (m, H-3), 3.50 (t, $J=$ $\left.9 \mathrm{~Hz}, \mathrm{H}-3^{\prime}\right), 3.58-3.61\left(\mathrm{~m}, 1 \mathrm{H}\right.$ from $\mathrm{OCH}_{2}$ and $\left.\mathrm{H}-4^{\prime}\right), 3.63(\mathrm{t}$, $\left.J=6 \mathrm{~Hz}, \mathrm{H}-5^{\prime \prime}\right), 3.66-3.71$ (m, H-4), 3.73 (dd, $J=12 \mathrm{~Hz}, J=$ $\left.3 \mathrm{~Hz}, \mathrm{H}-5^{\prime \prime}\right), 3.77$ (dt, $J=10 \mathrm{~Hz}, J=6.8 \mathrm{~Hz}, 1 \mathrm{H}$ from $\mathrm{OCH}_{2}$ ), 3.87 (dd, $\left.J=6 \mathrm{~Hz}, J=3 \mathrm{~Hz}, \mathrm{H}-3^{\prime \prime}\right), 3.91$ (dd, $J=11 \mathrm{~Hz}, J=$ $\left.5 \mathrm{~Hz}, \mathrm{H}-5^{\prime}\right), 3.98$ (dd, $\left.J=11 \mathrm{~Hz}, J=5 \mathrm{~Hz}, \mathrm{H}-5\right), 4.09$ (dd, $J=$ $\left.1.5 \mathrm{~Hz}, J=3 \mathrm{~Hz}, \mathrm{H}-2^{\prime \prime}\right), 4.08-4.11$ (m, H-4"), 4.33 (d, $J=8 \mathrm{~Hz}$, $\mathrm{H}-1), 4.40$ (d, $\left.J=8 \mathrm{~Hz}, \mathrm{H}-1^{\prime}\right), 5.23$ (d, $\left.J=1.5 \mathrm{~Hz}, \mathrm{H}-1^{\prime \prime}\right) ;{ }^{13} \mathrm{C}$ $\operatorname{NMR}\left(\mathrm{D}_{2} \mathrm{O}, 150 \mathrm{MHz}\right) \delta 13.2\left(\mathrm{CH}_{3}\right), 21.7,27.3,28.4\left(3 \times \mathrm{CH}_{2}\right)$, $61.2\left(\mathrm{C}-5^{\prime \prime}\right), 62.8(\mathrm{C}-5), 64.9\left(\mathrm{C}-5^{\prime}\right), 67.7\left(\mathrm{C}-4^{\prime}\right), 70.8\left(\mathrm{OCH}_{2}\right)$, $72.8\left(\mathrm{C}-2^{\prime}\right), 72.9$ (C-2), 73.8 (C-3), $76.4\left(\mathrm{C}-4+\mathrm{C}-3^{\prime}\right), 81.1\left(\mathrm{C}-2^{\prime}\right)$, $81.4\left(\mathrm{C}-3^{\prime}\right), 83.9$ (C-4"), 101.7 (C-1'), 102.7 (C-1), 108.1 (C-1"'); ESI-HRMS: $m / z$ calcd for $\mathrm{C}_{20} \mathrm{H}_{36} \mathrm{O}_{13} \mathrm{Na}:[\mathrm{M}+\mathrm{Na}]^{+}$: 507.2054, found: 507.2048 .

Pentyl- $\beta$-D-xylotrioside 4. Amorphous solid. $[\alpha]_{\mathrm{D}}^{20}-53.3(c$ 0.72 in $\mathrm{MeOH}) .{ }^{1} \mathrm{H} \mathrm{NMR}\left(\mathrm{D}_{2} \mathrm{O}, 500 \mathrm{MHz}\right): \delta 0.84(\mathrm{t}, J=7.0 \mathrm{~Hz}$, $3 \mathrm{H}), 1.22-1.32(\mathrm{~m}, 4 \mathrm{H}), 1.58(\mathrm{tt}, J=6.8 \mathrm{~Hz}, J=7.0 \mathrm{~Hz}, 2 \mathrm{H})$, $3.21\left(\mathrm{~m}, J=6.3 \mathrm{~Hz}, J=7.9 \mathrm{~Hz}, \mathrm{H}-2^{\prime}\right), 3.23(\mathrm{dd}, J=6.3 \mathrm{~Hz}, J=$ $7.9 \mathrm{~Hz}, \mathrm{H}-2), 3.25$ (dd, $\left.J=7.9 \mathrm{~Hz}, J=9.5 \mathrm{~Hz}, \mathrm{H}-2^{\prime \prime}\right), 3.27$ (dd, $\left.J=10.5 \mathrm{~Hz}, J=11.8 \mathrm{~Hz}, \mathrm{H}-5^{\prime \prime}\right), 3.30-3.37$ (m, H-5' and H-5), 
3.39 (dd, $\left.J=9.1 \mathrm{~Hz}, J=9.5 \mathrm{~Hz}, \mathrm{H}-3^{\prime}\right), 3.48-3.54$ (m, H-3 and H-3'), 3.58 (ddd, $J=5.5 \mathrm{~Hz}, J=9.1 \mathrm{~Hz}, J=10.5 \mathrm{~Hz}, \mathrm{H}-4^{\prime \prime}$ ), $3.63(\mathrm{dt}, J=6.8 \mathrm{~Hz}, J=9.8 \mathrm{~Hz}, 1 \mathrm{H}), 3.70-3.78\left(\mathrm{~m}, \mathrm{H}-4^{\prime}\right.$ and $\mathrm{H}-4), 3.82(\mathrm{dt}, J=6.8 \mathrm{~Hz}, J=9.8 \mathrm{~Hz}, 1 \mathrm{H}), 3.93(\mathrm{dd}, J=5.5 \mathrm{~Hz}$, $\left.J=11.8 \mathrm{~Hz}, \mathrm{H}-5^{\prime}\right), 4.03$ (dd, $\left.J=5.3 \mathrm{~Hz}, J=11.8 \mathrm{~Hz}, \mathrm{H}-5\right), 4.06$ $\left(\mathrm{dd}, J=5.3 \mathrm{~Hz}, J=11.8 \mathrm{~Hz}, \mathrm{H}-5^{\prime}\right), 4.38$ (d, $\left.J=7.9 \mathrm{~Hz}, \mathrm{H}-1\right)$, 4.42 (d, $\left.J=7.9 \mathrm{~Hz}, \mathrm{H}-1^{\prime \prime}\right), 4.44$ (d, $\left.J=7.9 \mathrm{~Hz}, \mathrm{H}-1^{\prime}\right) ;{ }^{13} \mathrm{C} \mathrm{NMR}$ $\left(\mathrm{D}_{2} \mathrm{O}, 125 \mathrm{MHz}\right) \delta 13.2\left(\mathrm{CH}_{3}\right), 21.7,27.2,28.4\left(3 \times \mathrm{CH}_{2}\right), 62.8$ (C-5), 62.9 (C-5'), 65.1 (C-5"), $69.1\left(\mathrm{C}-4^{\prime \prime}\right), 70.7\left(\mathrm{OCH}_{2}\right), 72.6$ (C-2'), 72.7 (C-2'), 72.9 (C-2), 73.6 (C-3), 73.8 (C-3'), 75.5 (C$\left.3^{\prime \prime}\right), 76.3$ (C-4 and C-4'), 101.6 (C-1'), 101.8 (C-1"), 102.7 (C-1); ESI-HRMS: $m / z$ calcd for $\mathrm{C}_{20} \mathrm{H}_{36} \mathrm{O}_{13} \mathrm{Na}:[\mathrm{M}+\mathrm{Na}]^{+}:$507.2054, found: 507.2050 .

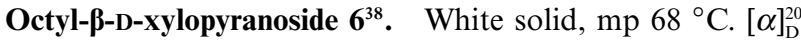
-40.2 (c 0.16 in $\mathrm{MeOH}) .{ }^{1} \mathrm{H}$ NMR $\left(\mathrm{D}_{2} \mathrm{O}, 500 \mathrm{MHz}\right): \delta 0.76(\mathrm{t}$, $J=6.9 \mathrm{~Hz}, 3 \mathrm{H}), 1.20-1.26\left(\mathrm{~m}, 5 \times \mathrm{CH}_{2}\right), 1.50(\mathrm{qu}, J=6.9 \mathrm{~Hz}$, $2 \mathrm{H}), 3.11(\mathrm{dd}, J=7.8 \mathrm{~Hz}, J=9.2 \mathrm{~Hz}, \mathrm{H}-2), 3.18(\mathrm{t}, J=11.4 \mathrm{~Hz}$, $\mathrm{H}-5), 3.29$ (t, $J=9.2 \mathrm{~Hz}, \mathrm{H}-3), 3.45-3.56$ (m, H-4, $1 \mathrm{H}$ from $\left.\mathrm{OCH}_{2}\right), 3.70-3.76\left(\mathrm{~m}, 1 \mathrm{H}\right.$ from $\left.\mathrm{OCH}_{2}\right), 3.81(\mathrm{dd}, J=5.2 \mathrm{~Hz}$, $J=11.4 \mathrm{~Hz}, \mathrm{H}-5), 4.25$ (d, $J=7.8 \mathrm{~Hz}, \mathrm{H}-1) ;{ }^{13} \mathrm{C} \mathrm{NMR}\left(\mathrm{D}_{2} \mathrm{O}\right.$, $125 \mathrm{MHz}) \delta 14.4\left(\mathrm{CH}_{3}\right), 23.1,26.2,29.5,29.6,29.9\left(5 \times \mathrm{CH}_{2}\right)$, 66.2 (C-5), 70.3 (C-4), $71.7\left(\mathrm{OCH}_{2}\right), 74.1$ (C-2), 76.9 (C-3), 104.1 (C-1); ESI-MS: $285.2(\mathrm{M}+\mathrm{Na})^{+}$.

Octyl- $\beta$-D-xylobioside $7^{38}$. White solid, mp $142{ }^{\circ} \mathrm{C} .[\alpha]_{\mathrm{D}}^{20}$ -56.8 (c 0.35 in $\mathrm{MeOH}) .{ }^{1} \mathrm{H}$ NMR $\left(\mathrm{D}_{2} \mathrm{O}, 500 \mathrm{MHz}\right): \delta 0.85(\mathrm{~m}$, $3 \mathrm{H}), 1.27-1.32\left(\mathrm{~m}, 5 \times \mathrm{CH}_{2}\right), 1.61(\mathrm{qu}, J=6.2 \mathrm{~Hz}, 2 \mathrm{H}), 3.24-3.30$ (m, H-2', H-2, H-5'), 3.34 (dd, $J=9.4 \mathrm{~Hz}, J=11.5 \mathrm{~Hz}, \mathrm{H}-5)$, $3.42\left(\mathrm{dd}, J=8.8 \mathrm{~Hz}, J=9.2 \mathrm{~Hz}, \mathrm{H}-3^{\prime}\right), 3.54(\mathrm{dd}, J=8.5 \mathrm{~Hz}, J=$ $9.4 \mathrm{~Hz}, \mathrm{H}-3), 3.57-3.64\left(\mathrm{~m}, \mathrm{H}-4^{\prime}\right.$ and $1 \mathrm{H}$ from $\left.\mathrm{OCH}_{2}\right), 3.75(\mathrm{dt}$, $J=4.8 \mathrm{~Hz}, J=9.4 \mathrm{~Hz}, \mathrm{H}-4), 3.79-3.85\left(\mathrm{~m}, 1 \mathrm{H}\right.$ from $\left.\mathrm{OCH}_{2}\right)$, $3.96\left(\mathrm{dd}, J=5.3 \mathrm{~Hz}, J=11.4 \mathrm{~Hz}, \mathrm{H}-5^{\prime}\right), 4.05(\mathrm{dd}, J=4.8 \mathrm{~Hz}$, $J=11.5 \mathrm{~Hz}, \mathrm{H}-5), 4.35$ (d, $J=7.7 \mathrm{~Hz}, \mathrm{H}-1), 4.43$ (d, $J=7.7 \mathrm{~Hz}$, $\left.\mathrm{H}-1^{\prime}\right) ;{ }^{13} \mathrm{C}$ NMR $\left(\mathrm{D}_{2} \mathrm{O}, 125 \mathrm{MHz}\right) \delta 13.2\left(\mathrm{CH}_{3}\right), 22.3,25.4,28.9$, 28.9, 29.1, $31.5\left(6 \times \mathrm{CH}_{2}\right), 62.9(\mathrm{C}-5), 65.2\left(\mathrm{C}-5^{\prime}\right), 69.1\left(\mathrm{C}-4^{\prime}\right)$, $70.4\left(\mathrm{OCH}_{2}\right), 72.6\left(\mathrm{C}-2^{\prime}\right), 72.9(\mathrm{C}-2), 73.9(\mathrm{C}-3), 75.6\left(\mathrm{C}-3^{\prime}\right)$, 76.2 (C-4), 101.8 (C-1'), 102.9 (C-1); ESI-HRMS: $m / z$ calcd for $\mathrm{C}_{18} \mathrm{H}_{34} \mathrm{O}_{9} \mathrm{Na}:[\mathrm{M}+\mathrm{Na}]^{+}:$417.2101, found: 417.2111.

Octyl-p-D-xylotrioside 8. White solid, mp $182^{\circ} \mathrm{C}$. $[\alpha]_{\mathrm{D}}^{20}-47.7$ (c 0.34 in $\mathrm{MeOH}) .{ }^{1} \mathrm{H}$ NMR $\left(\mathrm{D}_{2} \mathrm{O}, 500 \mathrm{MHz}\right): \delta 0.80-0.85(\mathrm{~m}$, $3 \mathrm{H}), 1.18-1.35$ (m, $10 \mathrm{H}), 1.35-165(\mathrm{~m}, 2 \mathrm{H}), 3.20-3.38$ (m, H-2, H-2', H-2" H-5", H-5, H-5'), 3.40 (dd, $J=9.1 \mathrm{~Hz}, J=9.5 \mathrm{~Hz}$, H-3"), 3.50-3.57 (m, H-3, H-3'), 3.58-3.68 (m, H-4"', 1H from $\left.\mathrm{OCH}_{2}\right), 3.70-3.79$ (m, H-4', H-4), 3.83 (m, $1 \mathrm{H}$ from $\left.\mathrm{OCH}_{2}\right), 3.95$ $\left(\mathrm{dd}, J=5.2 \mathrm{~Hz}, J=11.5 \mathrm{~Hz}, \mathrm{H}-5^{\prime \prime}\right), 4.00-4.15$ (m, H-5, H-5'), 4.38 (d, $J=7.6 \mathrm{~Hz}, \mathrm{H}-1), 4.44$ (d, $\left.J=8.0 \mathrm{~Hz}, \mathrm{H}-1^{\prime \prime}\right), 4.46$ (d, $J=$ $\left.8.0 \mathrm{~Hz}, \mathrm{H}-1^{\prime}\right) ;{ }^{13} \mathrm{C} \mathrm{NMR}\left(\mathrm{D}_{2} \mathrm{O}, 125 \mathrm{MHz}\right) \delta 13.2\left(\mathrm{CH}_{3}\right), 28.2(5 \times$ $\left.\mathrm{CH}_{2}\right), 28.6\left(\mathrm{CH}_{2}\right), 62.8\left(\mathrm{C}-5\right.$ and $\left.\mathrm{C}-5^{\prime}\right), 65.1\left(\mathrm{C}-5^{\prime \prime}\right), 69.0\left(\mathrm{C}-4^{\prime}\right)$, $70.5\left(\mathrm{OCH}_{2}\right), 72.5\left(\mathrm{C}-2^{\prime}\right), 72.7\left(\mathrm{C}-2\right.$ and $\left.\mathrm{C}-2^{\prime}\right), 73.6(\mathrm{C}-3$ and $\mathrm{C}-$ $\left.3^{\prime}\right), 75.5\left(\mathrm{C}-3^{\prime \prime}\right), 76.3$ (C-4 and C-4'), $101.6\left(\mathrm{C}-1^{\prime}\right), 101.7\left(\mathrm{C}-1^{\prime}\right)$, 102.7 (C-1); ESI-HRMS: $m / z$ calcd for $\mathrm{C}_{23} \mathrm{H}_{42} \mathrm{O}_{13} \mathrm{Na}$ : $[\mathrm{M}+\mathrm{Na}]^{+}$: 549.2523, found: 549.2516 .

The quantification of alkyl oligoxylosides with DP up to 3 was performed by HPLC using a RP-C18 column (Nucleodur 100$5 \mathrm{C} 18$ ec, $250 \times 4$, Macherey Nagel). Standard alkyl xylosides were purified as described above. Products were eluted at $0.6 \mathrm{~mL}$ $\min ^{-1}$ with a mobile phase composed of an acetonitrile: water mixture (20:80 for pentyl oligoxylosides and $40: 60$ for octyl oligoxylosides). The detection of eluates was performed with a dynamic light scattering detector (PL-ELS 1000, Polymer Laboratories).

\section{Pretreatment of wheat bran and sugar analysis}

Hydrothermal pretreatment was performed by incubating $10 \%$ (w/v) destarched wheat bran in water for $1 \mathrm{~h}$ at $135^{\circ} \mathrm{C}$ in an autoclave. The suspension was then filtered and the filtration cake was washed with water in order to recover the maximum solubilized oligoxylosides.

The sugar composition of commercial xylans, of destarched wheat bran and of the filtrate from the hydrothermally pretreated destarched wheat bran was determined after acid hydrolysis. Destarched wheat bran and commercial xylan $(10 \mathrm{mg})$ were hydrolysed with $125 \mu \mathrm{L}$ of $12 \mathrm{M} \mathrm{H}_{2} \mathrm{SO}_{4}$ for $2 \mathrm{~h}$ at room temperature whereas the filtrate obtained from pretreated wheat bran was hydrolysed at $100{ }^{\circ} \mathrm{C}$ for $1 \mathrm{~h}$ with $2 \mathrm{M} \mathrm{H}_{2} \mathrm{SO}_{4}$ with a ratio $1: 1(\mathrm{v}: \mathrm{v})$. After addition of $200 \mu \mathrm{L}$ of a solution of fucose $10 \mathrm{~g} \mathrm{~L}^{-1}$, samples were diluted with $675 \mu \mathrm{L}$ of water and incubated at $100{ }^{\circ} \mathrm{C}$ for $2 \mathrm{~h}$. After filtration, the samples were injected on CarboPac PA-1 column $(4 \times 250 \mathrm{~mm}$, Dionex $)$. Elution of monosaccharides was obtained with a $\mathrm{NaOH}-$ sodium acetate gradient as previously described. ${ }^{36}$ Detection was carried out by pulsed amperometry (ED 40, Dionex) and signal sensitivity was increased with a post-column module delivering $\mathrm{NaOH} 300 \mathrm{mM}$.

\section{Analysis of alkyl $\beta$-D-oligoxylosides surface active properties}

Upgraded reactions were performed in an IKA LR-2.ST reactor equipped with a double-walled reactor vessel with 2 liters capacity thermostated with a water bath and an anchor stirrer (IKA eurostar IKA Werke stirrer) which allows a vigorous stirring. The reaction media were then centrifugated for $10 \mathrm{~min}$ $(2000 \mathrm{~g})$ in order to pellet the residual xylan in the case of the synthesis of pentyl $\beta$-D-oligoxylosides and to separate the organic-based phase from the water-based phase in the case of the synthesis of octyl $\beta$-D-oligoxylosides. The supernantant containing the pentyl $\beta$-D-oligoxylosides and the organic-based phase containing octyl $\beta$-D-oligoxylosides were evaporated under reduced pressure and then dissolved in ultrapure deionized water.

Surface tension was measured by the Wilhelmy plate method with an automatic tensiometer (Krüss). The measurements concerning pentyl oligoxylosides were performed at $25^{\circ} \mathrm{C}$ and those concerning octyl oligoxylosides were performed at $40{ }^{\circ} \mathrm{C}$. The following commercial surfactant was used for comparison: butyl glucoside ORAMIX BG14 (Seppic, France). Samples and standards were diluted in ultrapure deionised water.

\section{Conclusions}

In this work, we have reported the enzymatic preparation of alkyl xylosides and oligoxylosides using two xylanases, various alcohols and different xylan sources. Whereas, xylan source influences the composition of alkyl oligoxylosides, the complexity of the reaction parameters that directly influences the yields and the DP of the products obtained has been pointed out. In the case of pentyl and octyl xylosides, optimal conditions 
in terms of donor and acceptor concentrations, enzyme charges, agitation, and presence of a co-solvent led to high yields of synthesis.

Wheat bran was evaluated as a potential source of pentoses for the synthesis of alkyl oligoxylosides. Conversion of xylooligosaccharides recovered after hydrothermal pretreatment of destarched wheat bran into alkyl xylosides was more efficient in terms of yields of alkyl pentosides than those obtained with polymeric xylans (birchwood xylan and xylans in non pretreated wheat bran). Pentyl and octyl oligoxylosides exhibited good surface properties. All our results demonstrate that the production of green surfactants can be envisaged from renewable resources converted with biotechnological methodologies.

\section{Acknowledgements}

This work was supported by the "CPER 2007-2013" (Pentoraf program). The authors are grateful to the "Région ChampagneArdenne" for a doctoral fellowship (M. O.) and material funds. We also thank Ms Chelan (A.R.D., Pomacle, France) and Ms Aubry (UMR FARE, Reims, France) for their technical help. NS-50030 xylanase was kindly provided by Novozymes (France).

\section{Notes and references}

1 J. H. Clark, V. Budarin, F. E. I. Deswarte, J. J. E. Hardy, F. M. Kerton, A. J. Hunt, R. Luque, D. J. Macquarrie, K. Milkowski, A. Rodriguez, O. Samuel, S. J. Tavener, R. J. White and A. J. Wilson, Green Chem., 2006, 8, 853-860.

2 S. Kim and B. E. Dale, Biomass Bioenergy, 2004, 26, 361375.

3 F. M. Girio, C. Fonseca, F. Carvalheiro, L. C. Duarte, S. Marques and R. Bogel-Lukasik, Bioresour. Technol., 2010, 101, 47754800 .

4 M. E. Zakrzewska, E. Bogel-Lukasik and R. Bogel-Lukasik, Energy Fuels, 2010, 24, 737-745.

5 C. Du, G. M. Campbell, N. Misailidis, F. Mateos-Salvador, J. Sadhukhon, M. Mustafa and R. M. Weightman, Chem. Eng. Res. Des., 2009, 87, 1232-1238.

6 J. Hollmann and M. G. Lindhauer, Carbohydr. Polym., 2005, 59, 225-230.

7 M. FitzPatrick, P. Champagne, M. F. Cunningham and R. A. Whitney, Bioresour. Technol., 2010, 101, 8915-8922.

8 S. J. Bennett and P. J. G. Pearson, Chem. Eng. Res. Des., 2009, 87, $1120-1139$.

9 B. Brehmer, R. M. Boom and J. Sanders, Chem. Eng. Res. Des., 2009, 87, 1103-1119.
10 K. Hill and O. Rhode, Eur. J. Lipid Sci. Technol., 1999, 101, 25-33. 11 W. von Rybinski, Curr. Opin. Colloid Interface Sci., 1996, 1, 587-597.

12 C. Damez, S. Bouquillon, D. Harakat, F. Henin, J. Muzart, I. Pezron and L. Komunjer, Carbohydr. Res., 2007, 342, 154-162.

13 H. Shinoyama, Y. Gama, H. Nakahara, Y. Ishigami and T. Yasui, Bull. Chem. Soc. Jpn., 1991, 64, 291-292.

14 F. Bouxin, S. Marinkovic, J. Le Bras and B. Estrine, Carbohydr. Res., 2010, 345, 2469-2473.

15 S. Marinkovic and B. Estrine, Green Chem., 2010, 12, 1929-1932.

16 F. van Rantwijk, M. W. V. Oosterom and R. A. Sheldon, J. Mol. Catal. B: Enzym., 1999, 6, 511-532.

17 A. Ismail, S. Soultani and M. Ghoul, J. Biotechnol., 1999, 69, 135143.

18 P. Turner, D. Svensson, P. Adlercreutz and E. N. Karlsson, J. Biotechnol., 2007, 130, 67-74.

19 J. Larsson, D. Svensson and P. Adlercreutz, J. Mol. Catal. B: Enzym., 2005, 37, 84-87.

20 A. Ducret, J. F. Carriere, M. Trani and R. Lortie, Can. J. Chem., 2002, 80, 653-656.

21 M. Gargouri, I. Smaali, T. Maugard, M. D. Legoy and N. Marzouki, J. Mol. Catal. B: Enzym., 2004, 29, 89-94.

22 M. Muzard, N. Aubry, R. Plantier-Royon, M. O'Donohue and C. Remond, J. Mol. Catal. B: Enzym., 2009, 58, 1-5.

23 H. Shinoyama, Y. Kamiyama and T. Yasui, Agricultural and Biological Chemistry, 1988, 52, 2197-2202.

24 N. Kadi and J. Crouzet, Food Chem., 2008, 106, 466-474.

25 N. Kadi, L. Belloy, P. Chalier and J. C. Crouzet, J. Agric. Food Chem., 2002, 50, 5552-5557.

26 Z. Jiang, Y. Zhu, L. Li, X. Yu, I. Kusakabe, M. Kitaoka and K. Hayashi, J. Biotechnol., 2004, 114, 125-134.

27 G. Mamo, S. Kasture, R. Faryar, S. Hashim and R. Hatti-Kaul, Process Biochem., 2010, 45, 700-705.

28 S. Matsumura, K. Sakiyama and K. Toshima, Biotechnol. Lett., 1999, 21, 17-22.

29 T. Nakamura, K. Toshima and S. Matsumura, Biotechnol. Lett., 2000, 22, 1183-1189.

30 D.-W. Park, H.-S. Kim, J.-K. Jung, S. Haam and W.-S. Kim, Biotechnol. Lett., 2000, 22, 951-956.

31 J. A. Pérez, I. Ballesteros, M. Ballesteros, F. Sáez, M. J. Negro and P. Manzanares, Fuel, 2008, 87, 3640-3647.

32 М. Ø. Petersen, J. Larsen and M. H. Thomsen, Biomass Bioenergy, 2009, 33, 834-840.

33 E. Papadopoulou, A. Hatjiissaak, B. Estrine and S. Marinkovic, Eur. J. Wood Prod., 2011, 69, DOI: 10.1007/s00107-010-0513-z in press.

34 D. Balzer, in Nonionic surfactants: alkyl polyglucosides, ed. D. Balzer and H. Lüders, Marcel Dekker, New York, 2000, vol. 91, p. 541.

35 F. Martel, B. Estrine, R. Plantier-Royon, N. Hoffmann and C. Portella, Top. Curr. Chem., 2010, 294, 79-115.

36 J. Beaugrand, G. Chambat, V. W. K. Wong, F. Goubet, C. Rémond, G. Paes, S. Benamrouche, P. Debeire, M. O'Donohue and B. Chabbert, Carbohydr. Res., 2004, 339, 2529-2540.

37 D. K. Kidby and D. J. Davidson, Anal. Biochem., 1973, 55, 321-325.

38 S. Matsumura, Y. Kinta, K. Sakiyama and K. Toshima, Biotechnol. Lett., 1996, 18, 1335-1340. 